\title{
Pendampingan Komunitas Tunarungu dalam Fortifikasi Kalsium Cangkang Telur pada Berbagai Penganan
}

\author{
Dwijowati Asih Saputri, Marlina Kamelia*, Nurhaida Widiani \\ Program Studi Pendidikan Biologi, Fakultas Tarbiyah dan Keguruan, Universitas Islam Negeri Raden Intan \\ Lampung, Sukarame, Bandar Lampung, Lampung, Indonesia
}

Submisi: 16 Januari 2019 ; Revisi: 23 Januari 2020; Penerimaan: 10 Februari 2020

\begin{abstract}
Kata Kunci: Abstrak Komunitas penyandang cacat, khususnya komunitas tunarungu di Gerkatin Bandar Lampung jumlahnya cukup banyak, yaitu 114 orang. Komunitas ini Limbah masih membutuhkan perhatian dari berbagai lapisan masyarakat agar mereka PAR memiliki keterampilan untuk hidup mandiri. Telur adalah salah satu makanan Wirausaha yang dikonsumsi oleh banyak orang Indonesia. Sekitar $10 \%$ bagian dari telur adalah cangkang. Provinsi Lampung, khususnya Kota Bandar Lampung berpotensi untuk menghasilkan limbah kulit telur. Setiap hari, sekitar $24.700 \mathrm{~kg}$ telur digunakan di Bandar Lampung dengan potensi kulit telur mencapai 2.470 $\mathrm{kg}$. Oleh karena itu, limbah cangkang telur bisa dimanfaatkan oleh komunitas tunarungu untuk fortifikasi berbagai penganan sehingga memiliki nilai tawar yang berbeda dengan produk sejenis. Strategi penerapan kegiatan pengabdian ini menggunakan empat tahapan, yaitu persiapan, implementasi, pelatihan, dan pemantauan. Kegiatan pemberdayaan yang dilaksanakan oleh tim pengabdi dari Universitas Islam Negeri Raden Intan Lampung dalam mengolah limbah cangkang telur sebagai bahan yang difortifikasi ke berbagai penganan dirasakan memberikan manfaat bagi komunitas tunarungu di Kota Bandar Lampung karena mereka dapat berwirausaha.
\end{abstract}

Keywords:

Abstract The number of people with disabilities, especially the deaf Entrepreneurship Gerkatin

PAR community in Bandar Lampung, is quite large, namely 114 people. This community still needs attention from various layers of the community so that they have the skills to live independently. Eggs are one of the foods consumed Waste by many Indonesians. About 10\% of the egg is a shell. Lampung Province, especially Bandar Lampung City tends to have a lot of eggshell waste. Everyday, around $24,700 \mathrm{~kg}$ of eggs are used in Bandar Lampung with potential eggshells waste reaching $2,470 \mathrm{~kg}$. Therefore, eggshell waste can be utilized by the deaf community for the fortification of various snacks so that it has a different bargaining value than similar products. The strategy for implementing this community service activity uses four stages, namely preparation, implementation, training, and monitoring. Empowerment activities carried out by the teams of devotees from Raden Intan Lampung State Islamic University in processing eggshell waste as fortified material to various foodstuffs felt to be beneficial for the deaf community in Bandar Lampung because they could be entrepreneurs. 


\section{PENDAHULUAN}

Manusia adalah makhluk ciptaan Allah yang paling sempurna, namun terkadang ada yang diberi ujian oleh Allah dengan dilahirkan dalam kondisi keterbatasan fungsi alat indra. Berdasarkan data dari UN Flagship Report on Disability and Development diketahui bahwa rata-rata di setiap negara terdapat $15 \%$ penyandang disabilitas pada 2018.

Mereka merupakan kelompok minoritas terbesar di dunia. Sekitar $82 \%$ dari penyandang disabilitas tersebut berada di negara-negara berkembang dan hidup di bawah garis kemiskinan serta kerap menghadapi keterbatasan akses kesehatan, pendidikan, pelatihan, dan pekerjaan yang layak (United Nation, 2018). Menurut Kepala Tim Riset Lembaga Penyelidikan Ekonomi dan Masyarakat Fakultas Ekonomika dan Bisnis Universitas Indonesia, jumlah penyandang difabel di Indonesia diperkirakan sebesar 12,15\% (LPEM, 2016).

Provinsi Lampung, khususnya Kota Bandar Lampung memiliki jumlah penyandang difabel cukup tinggi, yaitu mencapai 283 orang yang 114 orang di antaranya adalah penyandang tunarungu/wicara (Komisi Pemilihan Umum Kota Bandar Lampung, 2018). Penyandang difabel yang terdata di Provinsi Lampung, antara lain tunadaksa, tunanetra, tunarungu, dan tunagrahita. Penyandang tunarungu masih dalam usia produktif sehingga penting bagi mereka untuk mendapatkan keterampilan yang dapat dimanfaatkan guna meningkatkan taraf perekonomiannya.

Penyandang tunarungu di Bandar Lampung sering mendapatkan berbagai macam pelatihan keterampilan, baik dari Dinas Sosial Provinsi maupun Dinas Sosial Kota Bandar Lampung. Pelatihan tersebut diharapkan dapat membantu para penyandang tunarungu untuk hidup lebih mandiri. Meskipun telah mengikuti pelatihan keterampilan, masih ada penyandang tunarungu yang belum bisa hidup mandiri sehingga menjadi beban bagi keluarganya. Hal itu disebabkan oleh keterbatasan mereka dalam memahami materi sehingga belum mampu mengaplikasikan materi keterampilan yang telah diterima sebagai modal usaha.

Di Lampung, peraturan daerah tentang porsi tenaga kerja bagi kaum difabel belum ada sehingga menyulitkan mereka untuk memperoleh pekerjaan. Banyak perusahaan swasta yang tidak mau menerima kaum difabel sebagai tenaga kerja. Ketika kaum difabel dipekerjakan, terkadang mereka mendapatkan gaji yang lebih rendah daripada tenaga kerja normal. Selain itu, mereka juga kesulitan untuk mendapatkan formasi jabatan (Ningsih, 2014). Kondisi tersebut membuat kaum difabel di Bandar Lampung harus bisa berwirausaha supaya hidup lebih mandiri, sedangkan untuk berwirausaha dibutuhkan keterampilanketerampilan yang bisa dilakukan oleh mereka.
Berdasarkan data dari Kementerian Sosial diketahui bahwa hanya $39,61 \%$ penyandang disabilitas di Indonesia yang mengenyam pendidikan formal mulai jenjang SD hingga S3. Jumlah yang mengenyam pendidikan tinggi jauh lebih kecil, yaitu $0,56 \%$ (Kementerian Sosial, 2018). Penyandang tunarungu di Kota Bandar Lampung sudah diwadahi dalam sebuah organisasi bernama Gerakan untuk Kesejahteraan Tunarungu Indonesia (Gerkatin). Selain Gerkatin, masih ada beberapa organisasi dan komunitas-komunitas yang beranggotakan penyandang tunarungu di Bandar Lampung, antara lain Persatuan Tunarungu Indonesia (Perturi) dan Komunitas Mendengar yang beranggotakan keluarga dengan anak penyandang tunarungu. Pada umumnya organisasi-organisasi ini memiliki agenda rutin berupa pertemuan anggota. Pada pertemuan tersebut biasanya dibicarakan berbagai pengalaman usaha serta saling berbagi ilmu dan keterampilan dalam rangka kemandirian usaha bagi kaum tunarungu. Penyandang tunarungu yang menjadi anggota berbagai organisasi tersebut pada umumnya pernah mendapatkan pendidikan formal dari Sekolah Luar Biasa. Adapun penyandang tunarungu yang tidak pernah mendapatkan pendidikan formal dan belum terhimpun dalam berbagai organisasi akan sulit untuk hidup mandiri karena mereka sulit mendapatkan informasi dan keterampilan.

Berdasarkan hasil wawancara dengan Sekretaris Gerkatin Bandar Lampung, Chandra Wijaya, diketahui bahwa saat ini jumlah anggota Gerkatin Bandar Lampung kurang lebih 150 orang. Dari jumlah tersebut, sekitar $15 \%$ saat ini sudah bekerja. Beberapa pekerjaan yang dapat dilakukan adalah ojek online, menjahit, membuka steam motor, berjualan makanan, membuka bengkel, dan menjual jasa massage online. Beberapa anggota masih bersekolah di tingkat SMP dan SMA. Akan tetapi, banyak juga yang tidak dapat mengenyam pendidikan formal.

Komunitas difabel, khususnya di Bandar Lampung masih memerlukan perhatian dari berbagai lapisan masyarakat, termasuk para dosen yang bisa membantu dengan mengaplikasikan ilmunya melalui kegiatan Tridarma Perguruan Tinggi, khususnya kegiatan pengabdian kepada masyarakat. Kegiatan pendampingan yang dilakukan oleh tim pengabdi dari Universitas Islam Negeri Raden Intan ini dilakukan dengan memberikan pelatihan perihal pemanfaatan cangkang kulit telur untuk dijadikan bahan fortifikasi pangan. Kegiatan pengabdian masyarakat ini diharapkan dapat memberikan pemahaman dan keterampilan bagi komunitas difabel dalam mengelola limbah cangkang telur untuk dijadikan makanan yang bernilai gizi. Hal tersebut diharapkan akan berdampak pada peningkatan taraf kesehatan dan perekonomian, khususnya komunitas difabel dan masyarakat Kota Bandar Lampung pada umumnya. Pemanfaatan potensi cangkang kulit telur sebagai bahan 
fortifikasi makanan bisa dijadikan sebagai usaha rumahan oleh penyandang difabel karena mereka tidak harus terlalu banyak berkomunikasi secara verbal.

Cangkang telur biasanya dibuang dan dapat mencemari lingkungan. Cangkang telur sering kali hanya dianggap sebagai limbah yang tidak bisa dimanfaatkan, padahal cangkang telur mengandung banyak zat yang dapat menjadi senyawa pendukung untuk kesehatan tubuh. Cangkang telur hampir 95\% mengandung bahanbahan anorganik, 3,3\% bahan organik (terutama protein), dan 1,6\% air (Umar, 2000). Stadelman \& Owen (1989) mengatakan bahwa sebagian besar bahan anorganik pada cangkang telur terdiri atas sekitar $94 \%$ persenyawaan kalsium karbonat $\left(\mathrm{CaCO}_{3}\right)$ dan sekitar $1 \%$ magnesium karbonat $\left(\mathrm{MgCO}_{3}\right)$. Adapun protein yang membentuk cangkang telur terdiri atas lapisan membran protein yang membentuk musin dan kretin (Indah, 2017).

Salah satu alternatif yang dapat dilakukan untuk memanfaatkan potensi limbah cangkang telur adalah dengan mengolah cangkang telur menjadi sumber kalsium alternatif yang dapat difortifikasikan pada bahan pangan, seperti bolu, donat, puding, dan es krim. Kalsium yang difortifikasikan pada makanan akan dapat mencukupi kebutuhan kalsium harian (sekitar 7001.300 mg), baik anak-anak maupun lansia. Kalsium yang diekstraksi dari cangkang telur dapat dijadikan bahan tambahan mineral pangan pada makanan. Cangkang telur halus dalam setiap 1 sendok teh $( \pm 4$ gr) setara dengan 1.000 mg kalsium (Inderawati, 2017). Kalsium berkaitan erat dengan pembentukan tulang dan gigi; pengaturan aktivitas sel yang vital; pengaturan fungsi saraf dan otot; pengaturan kerja hormon; pembekuan darah; dan mobilitas seluler.

Pendekatan yang dilakukan melalui kegiatan pengabdian ini juga diharapkan dapat membantu deradikalisasi yang mungkin timbul akibat kurangnya perhatian terhadap komunitas tunarungu. Sumbangsih yang bisa diberikan dalam mengatasi deradikalisasi dapat berupa pendekatan verbal dan nonverbal. Pendekatan verbal berupa membangun kedekatan dan kepercayaan pada saat pelaksanaan kegiatan pengabdian sehingga memungkinkan bagi para pengabdi untuk memberikan pemahaman tentang bahaya radikalisasi bagi kehidupan, baik sosial maupun ekonomi. Adapun pendekatan nonverbal berupa sikap santun dan peduli yang senantiasa ditunjukkan selama proses pengabdian sehingga memberikan teladan dan kesadaran pribadi untuk menghindari sikap radikal tanpa perlu diminta atau dipaksa.

Berdasarkan uraian di atas dapat disimpulkan bahwa pemberdayaan komunitas difabel dalam mengelola limbah cangkang telur menjadi substituen dalam makanan perlu dilakukan. Oleh karena itu, kegiatan pengabdian "Pendampingan Komunitas Tunarungu dalam Fortifikasi Kalsium Cangkang Telur pada Berbagai Penganan” penting untuk dilaksanakan. Tujuan pelaksanaan kegiatan pengabdian ini adalah untuk memberikan pendampingan kepada komunitas tunarungu di Bandar Lampung dalam mengolah limbah cangkang telur menjadi bahan fortifikasi makanan. Kegiatan ini diharapkan dapat memberikan keterampilan yang akan berdampak pada peningkatan taraf kesehatan dan perekonomian, khususnya komunitas tunarungu di Bandar Lampung dan masyarakat Kota Bandar Lampung pada umumnya.

Berdasarkan latar belakang kondisi mitra dampingan di atas dapat dikemukakan beberapa rumusan masalah yaitu upaya-upaya apakah yang dapat dilakukan dalam memberikan wawasan kepada komunitas tunarungu agar dapat melakukan fortifikasi limbah cangkang telur pada berbagai macam penganan. Komunitas tunarungu yang telah diberikan wawasan selanjutnya diupayakan mampu mempraktikkan fortifikasi limbah cangkang telur pada berbagai macam penganan. Selanjutnya, melihat upaya-upaya apakah yang dapat dilakukan agar komunitas tunarungu mampu membagikan keterampilan yang diperolehnya kepada penyandang tunarungu lainnya di lingkungan masingmasing.

\section{METODE}

Model pendekatan dalam pelaksanaan pemberdayaan yang dilakukan pada kegiatan pengabdian ini adalah participatory action research (PAR) pada komunitas difabel. Pendekatan ini mengajak komunitas difabel untuk berpartisipasi dalam mengolah limbah cangkang telur sehingga terbangun kesadaran diri bahwa mereka mampu untuk mengolah limbah menjadi produk yang dapat dimanfaatkan. Setelah berpartisipasi dengan segala kekurangan yang dimiliki, kaum difabel diharapkan akan mampu meningkatkan kemampuan ekonomi, baik dirinya sendiri maupun komunitasnya, serta bermanfaat bagi orang lain.'

\subsection{Tahap perencanaan pemberdayaan}

Tahap perencanaan pemberdayaan meliputi survei sebagai bentuk analisis kebutuhan, pemantapan dan penentuan lokasi serta sasaran, penyusunan bahan/materi pelatihan yang meliputi makalah dan modul untuk kegiatan pemberdayaan pembuatan tepung dari cangkang telur sebagai bahan fortifikasi pangan oleh komunitas difabel Kota Bandar Lampung. Materi diberikan kepada komunitas tunarungu dengan menerapkan strategi pembelajaran "jigsaw", yaitu transfer ilmu dari satu kelompok kecil ke kelompok lainnya. Penerapan materi dengan strategi tersebut akan dibantu oleh mediator dari Gerkatin Kota Bandar Lampung. Mediator akan membantu untuk memberi penjelasan kepada lima orang penyandang tunarungu yang terpilih. Lima orang yang sudah mendapatkan materi tersebut kemudian diminta 
untuk membagikan pemahamannya kepada tujuh orang lainnya.

\subsection{Tahap pelaksanaan}

Tahap pelaksanaan meliputi pelatihan pembuatan tepung dari limbah cangkang telur serta pendampingan pembuatan penganan terfortifikasi tepung cangkang telur. Pelatihan pembuatan tepung dari limbah cangkang telur dimulai dengan mengumpulkan dan menyortir cangkang yang akan digunakan. Cangkang yang digunakan berasal dari telur ayam saja. Setelah dikumpulkan, cangkang dibuang kulit arinya dan dicuci hingga bersih lalu ditiriskan dan dijemur hingga kering. Setelah kering, cangkang dimasukkan ke oven untuk menghilangkan bakteri yang mungkin masih menempel. Cangkang yang sudah kering kemudian digiling hingga halus dan menjadi tepung. Tepung tersebut kemudian diayak hingga diperoleh tepung yang benar-benar halus sehingga tidak menimbulkan tekstur yang berbeda saat difortifikasi pada penganan.

Tepung cangkang telur dapat difortifikasi pada berbagai jenis penganan. Pada kegiatan ini, tepung cangkang telur difortifikasi pada produk pangan, seperti puding lumut, brownies, donat, es krim, serta bolu tapai keju. Penganan ini dipilih karena mudah diaplikasikan dan bahan mudah didapat.

\subsection{Tahapan pemonitoran dan evaluasi}

Tahapan pemonitoran dan evaluasi dilakukan setelah pendampingan. Pemonitoran bertujuan untuk melihat tingkat efektivitas pendampingan yang dilakukan, yakni apakah memberikan manfaat atau tidak untuk kemandirian komunitas tunarungu. Tahapan setelah pemonitoran adalah evaluasi yang dilakukan untuk menganalisis kekurangan ataupun hambatan yang dihadapi komunitas tunarungu di lapangan dalam mengaplikasikan ilmu yang sudah didapatkan. Hasil evaluasi menjadi dasar untuk mencari solusi atas kendala-kendala yang dihadapi.

\section{HASIL DAN PEMBAHASAN}

Komunitas difabel, khususnya tunarungu memiliki berbagai kekurangan, terutama dalam berkomunikasi karena kurangnya kemampuan mendengar. Suparno (2001) mengatakan bahwa keterbatasan persepsi auditory dan kurangnya kemampuan berbahasa menyebabkan penyandang tunarungu mengalami ketidakstabilan emosi, frustrasi, dan rasa kecewa dalam interaksi sosialnya. Rasa frustrasi dalam interaksi sosial menyebabkan penyandang tunarungu sulit menjalankan usaha. Dengan demikian, komunitas tunarungu sebagai salah satu komunitas difabel harus mendapatkan perhatian khusus dan diberdayakan supaya hidup lebih mandiri. Hal tersebut sesuai amanat Undang-Undang Republik Indonesia No. 8 Tahun 2016 tentang
Penyandang Difabel, Bab 1, Pasal 1 No. 7 yang menjelaskan bahwa "Pemberdayaan adalah upaya untuk menguatkan keberadaan penyandang difabel dalam bentuk penumbuhan iklim dan pengembangan potensi hingga mampu dan berkembang menjadi individu atau kelompok penyandang difabel yang tangguh dan mandiri".

Kegiatan pemberdayaan komunitas difabel, khususnya komunitas tunarungu di Kota Bandar Lampung ini dilakukan berdasarkan prinsip pemberdayaan yang disampaikan oleh Soetomo (2013), yakni fokus atau kegiatan adalah masyarakat atau komunitas dengan mengedepankan partisipasi, prakarsa, kebutuhan, dan swadaya masyarakat. Osmani (2000) menjelaskan bahwa pemberdayaan adalah sebuah kondisi ketika orang atau kelompok yang tidak berdaya menciptakan situasi sedemikian rupa sehingga mampu menyampaikan keinginannya. Adapun prinsip pemberdayaan masyarakat menurut Mardikanto \& Poerwoko (2012) adalah menggunakan metode yang tepat, kerja sama dan partisipasi, minat dan kebutuhan, demokratis, sasarannya adalah kelompok masyarakat bawah, terarah dan spesifik, tenaga fasilitator yang spesifik, memperhatikan keragaman budaya komunitas yang didampingi, serta melibatkan pemuka masyarakat.

Pengabdian masyarakat ini menyasar kepada komunitas tunarungu, yaitu Gerkatin Kota Bandar Lampung. Kegiatan pengabdian disesuaikan dengan kebutuhan komunitas tersebut. Kegiatan diawali dengan survei tentang kegiatan Gerkatin yang dilanjutkan dengan FGD bersama pengurus dan anggota Gerkatin cabang Bandar Lampung. Berdasarkan hasil FGD diperoleh informasi bahwa anggota Gerkatin yang telah memiliki pekerjaan tetap hanya sekitar $20 \%$ dari \pm 150 anggota. Berdasarkan identifikasi dalam kegiatan FGD disimpulkan bahwa kegiatan pemberdayaan komunitas tunarungu di Bandar Lampung penting dilakukan.

Haris (2014) mengatakan bahwa kegiatan pemberdayaan masyarakat diarahkan untuk meningkatkan harkat dan martabat manusia sehingga mampu keluar dari perangkap ketidakberdayaan dan keterbelakangan, menjadikan mandiri, dan tidak tergantung pada individu atau kelompok lain untuk memenuhi kebutuhan dasarnya. Pendapat ini juga didukung oleh Suharto (2005) yang mengatakan bahwa salah satu unsur penting dalam kegiatan pemberdayaan masyarakat adalah penguatan dan pengembangan kapasitas. Penguatan kapasitas bagi penyandang tunarungu dalam kegiatan ini adalah untuk meningkatkan kemampuan membuat tepung dari cangkang telur yang akan digunakan untuk fortifikasi pada produk penganan sehingga bernilai gizi tinggi. Produk penganan bersuplemen tepung cangkang telur memiliki nilai jual yang lebih tinggi sehingga diharapkan mampu 
meningkatkan usaha penjualan penganan yang telah dirintis oleh Gerkatin.

Upaya pengembangan kapasitas penyandang tunarungu di Kota Bandar Lampung dalam membuat tepung dari limbah cangkang telur dilakukan dengan mengadakan kegiatan kedua, yaitu pelatihan. Pelatihan dipandu oleh fasilitator sebagai penerjemah materi yang disampaikan oleh pelatih kepada peserta dengan menggunakan bahasa isyarat. Pelatihan ini dilakukukan dengan model jigsaw untuk memaksimalkan pemahaman peserta terhadap materi yang disampaikan (Gambar 1). Komunitas tunarungu memiliki keterbatasan dalam komunikasi oral sehingga apabila beberapa orang peserta dari kelompok kecil yang sudah memahami materi kemudian menyampaikan kepada anggota kelompoknya dengan bahasa mereka, materi pelatihan diharapkan dapat lebih mudah dipahami oleh penyandang tunarungu yang lain. Pelatihan ini diharapkan dapat meningkatkan keterampilan anggota Gerkatin yang mengikuti pelatihan.

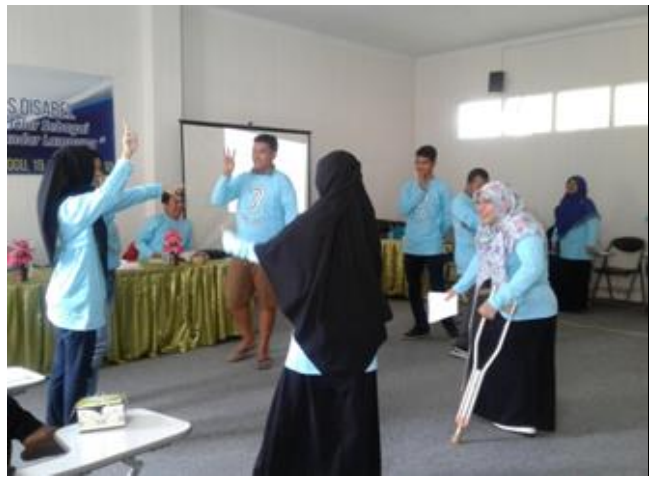

Gambar 1. Penjelasan kepada perwakilan setiap kelompok dengan model jigsaw

Kegiatan berikutnya adalah pendampingan fortifikasi tepung limbah cangkang telur ke berbagai jenis penganan agar dosisnya tepat (Gambar 2). Dalam kegiatan ini dipraktikkan pembuatan es krim dan beberapa jenis kue, antara lain puding lumut, brownies, donat, serta bolu tapai keju (Gambar 3). Tim pengabdi juga menjelaskan bahwa tepung cangkang telur bisa menjadi suplemen pada jenis penganan yang lain. Dalam kegiatan pendampingan ini, metode PAR yang digunakan adalah proses aktif yang inisiatifnya dilakukan oleh komunitas dan dibimbing serta diawasi melalaui mekanisme tertentu secara efektif (Suwartiningsih, 2015). Metode PAR adalah metode yang melibatkan semua pihak yang berkepentingan dalam mengkaji tindakan secara langsung dalam rangka melakukan perubahan dan perbaikan ke arah yang lebih baik.

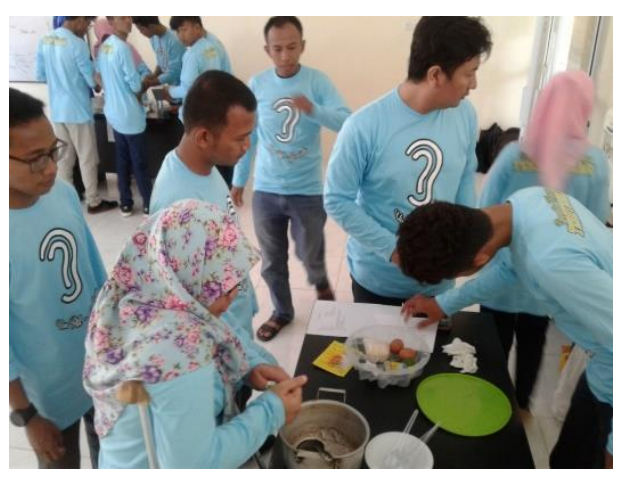

Gambar 2. Pendampingan fortifikasi tepung limbah cangkang telur menjadi berbagai jenis penganan

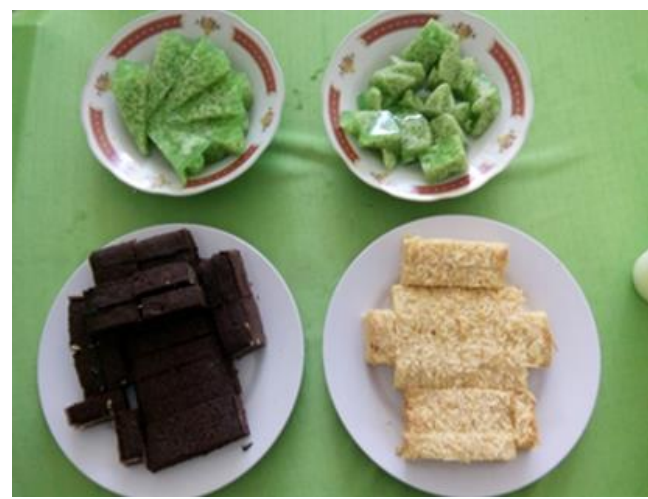

Gambar 3. Produk hasil pelatihan pendampingan fortifikasi tepung limbah cangkang telur menjadi berbagai jenis penganan

Kegiatan berikutnya adalah pemonitoran terhadap pemasaran produk penganan bersuplemen tepung cangkang telur pada usaha penjualan penganan yang dimiliki oleh Gerkatin. Hasil pemonitoran menunjukkan bahwa Gerkatin telah memanfaatkan tepung limbah cangkang telur untuk memfortifikasi penganan dan telah melakukan kegiatan penjualan. Namun demikian, penganan yang telah difortifikasi dan dijual oleh Gerkatin masih terbatas, yakni hanya kue donat saja. Pada kegiatan pemonitoran ini juga disebar angket uji organoleptik kepada para konsumen yang juga berperan sebagai panelis. Uji organoleptik dilakukan terhadap tiga puluh konsumen.

Ayustaningwarno (2014) menjelaskan bahwa ada tujuh macam panelis, yaitu panelis perseorangan, panelis terbatas, panelis terlatih, panelis agak terlatih, panelis konsumen, dan panelis anak-anak. Panelis konsumen terdiri atas 30-100 orang target, tergantung pada target pemasaran komoditas. Panelis konsumen mempunyai sifat yang sangat umum. Selain itu, ada empat skala penilaian, yaitu 4) sangat suka, 3) suka, 2) tidak suka, dan 1) sangat tidak suka. Empat skala penilaian itu diterapkan pada empat aspek kualitas penganan yang meliputi aroma, rasa, tekstur, dan warna (Tabel 1). Wahyuningtias (2019) mengatakan bahwa yang menentukan diterima atau tidaknya suatu produk pangan adalah penilaian indrawi atau yang disebut uji organoleptik. Indra yang digunakan adalah penglihatan yang berhubungan dengan warna, indra pembau yang 
berkaitan dengan aroma, indra perasa (lidah) atau pengecap yang berkaitan dengan rasa, dan indra peraba yang berkaitan dengan tekstur penganan. Tekstur penganan juga bisa dengan mudah dirasakan menggunakan mulut saat dikunyah. Hasil uji organoleptik terhadap produk penganan dengan fortifikasi tepung cangkang telur dapat terlihat pada Tabel 1.

Tabel 1. Hasil uji organoleptik produk penganan berfortifikasi tepung cangkang telur

\begin{tabular}{lcccc}
\multicolumn{1}{r}{ Skor } & & & & \\
Aspek & $\mathbf{4}$ & $\mathbf{3}$ & $\mathbf{2}$ & $\mathbf{1}$ \\
\hline Aroma & & & & \\
Rasa & $28 \%$ & $72 \%$ & - & - \\
Tekstur & - & $83 \%$ & $17 \%$ & - \\
Warna & $10 \%$ & $71 \%$ & $20 \%$ & - \\
& $27 \%$ & $54 \%$ & $19 \%$ & -
\end{tabular}

Komunitas tunarungu setelah mendapatkan pelatihan fortifikasi limbah cangkang telur pada penganan kemudian membuka gerai penganan. Gerai penganan awalnya hanya buka 2 sampai 3 kali seminggu dengan berpindah-pindah tempat. Seiring waktu, gerai penganan frekuensi bukanya meningkat hingga 5 sampai 6 kali seminggu dan menetap agar dapat mudah dicari pelanggannya. Selain membuka gerai, salah satu anggota Gerkatin yang terlibat dalam pelatihan pembuatan tepung limbah cangkang telur telah membuka usaha donat yang diberi nama "donat_ramama97". Donat tersebut dipasarkan di toko penganan dan secara on-line melalui media sosial instagram.

Pengabdian kepada masyarakat yang dilakukan pada komunitas tunarungu di Bandar Lampung telah diupayakan agar sesuai dengan kebutuhan komunitas tersebut. Setianingsih dan Gutama (2016) mengatakan bahwa kemandirian adalah salah satu tujuan yang harus diperoleh komunitas difabel (khususnya penyandang tunarungu). Dari sisi psikologi, kegiatan pengabdian ini penting dilaksanakan karena mampu meningkatkan rasa percaya diri akibat diskriminasi masyarakat terhadap penyandang tunarungu (Mulyati et al., 2019). Namun demikian, pelatihan dihadapkan pada berbagai tantangan. Tantangan pertama adalah sulitnya berkoordinasi dengan pengurus Gerkatin karena tidak adanya sekretariat dan tempat tinggal pengurus yang berjauhan (pengurus Gerkatin berasal dari kecamatan yang berbeda-beda di Bandar Lampung). Persoalan ini dapat diatasi dengan memaksimalkan komunikasi menggunakan media sosial, seperti WhatsApp dan Instagram. Komunikasi juga dijalin dengan fasilitator Gerkatin untuk membantu berkoordinasi dengan pengurus Gerkatin.
Tantangan kedua adalah kurangnya minat anggota Gerkatin yang terlibat langsung dalam kegiatan pemberdayaan ketika mengikuti kegiatan tersebut karena tidak semua memiliki minat terhadap usaha pembuatan dan penjualan penganan. Hal tersebut diatasi dengan terus memberi motivasi melalui pendekatan, baik secara langsung maupun tidak langsung. Pendekatan secara langsung dilakukan pada saat acara pertemuan Gerkatin. Motivasi diberikan kepada anggota Gerkatin agar terus berusaha hidup lebih mandiri, yakni dengan belajar untuk berwirausaha dalam wadah usaha bersama yang telah dimiliki oleh Gerkatin. Adapun pendekatan secara tidak langsung dilakukan dalam grup media sosial Gerkatin. Mereka memberi motivasi dan tawaran solusi atas berbagai masalah yang dihadapi dalam menjalankan usaha bersama yang telah dimiliki Gerkatin.

\section{KESIMPULAN}

Berdasarkan hasil pelaksanaan kegiatan pemberdayaan, komunitas tunarungu telah memiliki wawasan mengolah limbah cangkang telur menjadi bahan fortifikasi penganan. Peserta dampingan telah mampu mengaplikasikan limbah cangkang telur sebagai bahan fortifikasi dalam penganan seperti bolu tapai keju, brownies, serta puding lumut. Hasil evaluasi kegiatan dampingan menunjukkan bahwa peserta dampingan telah mampu menjadikan keterampilan yang diperoleh sebagai sarana wirausaha. Hal ini tampak pada dibukanya gerai yang menjual penganan terfortifikasi limbah cangkang telur yaitu donat.

\section{Ucapan Terima Kasih}

Kami mengucapkan terima kasih kepada Subdit Penelitian dan Pengabdian kepada Masyarakat Direktorat Pendidikan Tinggi Islam Kementerian Agama Republik Indonesia yang telah memberikan dana hibah "Pengabdian Masyarakat Terintegrasi" sehingga kegiatan ini dapat dilaksanakan. Selain itu, ucapan terima kasih disampaikan kepada seluruh tim PMC yang telah memberi dukungan, partisipasi, dan kerja sama yang baik selama pelaksanaan kegiatan.

\section{Referensi}

Ayustaningwarno, F. (2014). Teknologi Pangan: Teori Praktis dan Aplikasi. Semarang: Graha Ilmu.

Haris, A. (2014). Memahami Pendekatan Pemberdayaan Masyarakat Melalui Pemanfaatan Media. JUPITER, 10(1), 50-62.

Indah, A. (2017). Kandungan dan Manfaat Cangkang telur dalam Industri Pangan. Diakses dari https://www.kompasiana.com/afifahindahn/58bdf 3d3a3afb deb10b3a1cf/kandungan-dan-manfaatcangkang-telur-dalam-industri-pangan 
Inderawati, D. M. (2017). Panduan Kebutuhan Kalsium Harian. Diakses dari https://www.klikdokter.com/rubrik/read/2700225/ panduan-kebutuhan-kalsium-harian

KPU Kota Bandar Lampung. (2018). Miniatur Pemilu untuk Kaum Difabel. Diakses dari http://www. kpu-bandarlampung.go.id

Kementerian Sosial. (2018). Kementerian Sosial dalam Angka. Jakarta: Badan Pendidikan dan Penelitian Kesejahteraan Sosial Pusat Data dan Informasi Kesejahteraan Sosial.

LPEM Fakultas Ekonomi dan Bisnis. (2016). Menuju Inklusifitas Penyandang Disabilitas di Pasar Kerja Indonesia. Diakses dari https://www.lpem.org/wpcontent/uploads/2016/12/Lembar-fakta-rev5.pdf

Mardikanto, T. \& Poerwoko, S. (2013). Pemberdayaan Masyarakat dalam Perspektif Kebijakan Publik. Bandung. Alfabeta.

Mulyati, T. A., Rohmatiah, D.N., \& Amadi. (2019). Pelatihan dan Pendampingan Penyandang Disabilitas Desa Simbatan, Kecamatan Nguntoronadi, Kabupaten Megetan. Jurnal Terapan Abdimas, 4(2), 187-191.

Ningsih, E. R. (2014). Mainstreaming Isu Difabel di Masyarakat dalam Kegiatan Penelitian maupun Pengabdian pada Masyarakat di STAIN Kudus. Jurnal Penelitian, 8(1).

Osmani. (2000). Paticipatory Governance, People's Empowerment and Poverty. Washington-UNDP.

Soetomo. (2013). Pemberdayaan Masyarakat. Yogyakarta: Pustaka Pelajar.

Suwartiningsih. (2015). Implementasi PAR dalam Pendidikan Agama Islam. Jurnal PARADIGMA, 2(1), 1-9.

Suharto, E. (2005). Membangun Masyarakat Memberdayakan Rakyat. Bandung: Refika Ditama.

Suparno. (2001). Pendidikan Anak Tunarungu. Yogyakarta: PLB FIP UNY.

Setianingsih, R. \& Th. A. Gutama. (2016). Pengembangan Kemandirian bagi Kaum Difabel (Studi Kasus pada Peran Paguyuban Sehati dalam Upaya Pengembangan Kemandirian Kaum Difabel di Kabupaten Sukoharjo). Jurnal Sosiologi DILEMA, 31(1), 1-11.

Stadelman, W. J. \& Owen J. C. (1989). Egg Science and Technology ( $2^{\text {nd }}$ ed.). AVI Publishing Company, Inc. Westport, Connecticut.

Umar. (2000). Kualitas Fisik Telur Ayam Kampung di Pasar Tardisional, Swalayan, dan Peternak di Kota Bogor (Skripsi). Fakultas Pertanian, Institut Pertanian Bogor, Bogor.

United Nation. (2018). Flagship Report on Disability and Development. Diakses dari https://www.un.org/development/desa/disabilities /wp-content/uploads/sites/ 15/2018/12/UNFlagship-Report-Disability.pdf

Undang-Undang No. 8 Tahun 2016 tentang Penyandang Disabilitas
Wahyuningtias, D. (2019). Uji Organoleptik Hasil Kue Menggunkan Bahan Instan dan Noninstan. Binus Bussiness Review, Vol 1(1), 116-125. 